\title{
Experimental Investigation on Higher Proportion Esters of Simarouba Glauca in DI Diesel Engine
}

\author{
Karthikayan.S 1 , Sankaranarayanan.G 2 \\ ${ }^{1}$ Research Scholar, Department of Mechanical Engineering, Sathyabama University, Chennai - 600 119, India. \\ 2Sree Sastha Institute of Engineering and Technology, Chennai - 600 123, India. \\ Email.sskksmit@gmail.com
}

\section{Abstract}

The economy of a nation depends on the surface transport. The diesel engine is the main prime mover of the surface transport. Further, the galloping fuel prices and ever increasing fuel demands compel the researchers to focus on alternative fuel. Dr.Rudolf diesel was a pioneer to run his engine with peanut oil in Paris during 1905. Due to the higher energy content of vegetable oils i.e. nearly $80 \%-90 \%$ of that of the diesel fuel and high cetane number of the vegetable oils are the most suitable factors for diesel engine. However, the viscosity is the only constrain and to overcome that the fuel modification is the one possible method to use the vegetable oil effectively. The use of non edible vegetable oil as fuel helps the agriculturist to reduce the dependability of fossil fuel. The bio fuels increase employability and reduce the rural migration to metro cities. Further, the rural economy will be strengthened. This paper is focused on the use of Simarouba Glauca esters and its blends with diesel as fuel starting from $60 \%, 70 \%, 80 \%, 90 \%$ and $100 \%$ respectively in a single cylinder constant speed direct injection diesel engine. The results are very encouraging that the performance and emission of the higher blends and SGE 100 is worth mentioning.

Abbreviations and Acronyms: SGE-Simarouba Glauca Ester, DI-Direct Injection, CO-Carbon monoxide, HC- Hydrocarbon, NOx-Oxides of nitrogen, CO2-Carbon-di-oxide, BSFC-Brake specific fuel consumption, NA-Naturally aspirated, TDC-Top Dead Center, BTE-Brake thermal efficiency.

\section{INTRODUCTION}

Depletion of fossil fuel, environmental degradations and fuel crisis occurs due to the increase of surface transport. Many researchers focus on the area of alternative fuel. Biodiesel produced from vegetable oil and animal fats are more potential to alternate conventional fuels. Biodiesel are successfully tested in various engines and found that the suitability, performance, emission and combustion characteristics were efficient. Zafer Uulu et.al [1] have studied waste frying oil on $\mathrm{DI}$ diesel engine and have found that $\mathrm{CO}$ $(17.4 \%)$ and NOx emissions have decreased by $1.45 \%$; the intensity of smoke is increased by $22.46 \%$. The exhaust gas temperature of ester in waste frying oil is decreased by $6.5 \%$. Pugazhvadivu et.al [2] used preheated waste frying oil as fuel in direct injection $\mathrm{Cl}$ engine. By preheating the high viscous fuel to $135^{\circ} \mathrm{C}$, viscosity was reduced, BSFC \& BTE increased, $\mathrm{CO}$ and Smoke were reduced.

Balajee et al.[22] had tested the effect of pogamia \& jatropha blends in diesel engine and found that the performance was lower than neat diesel and emissions had increased. Ramadha's et.al [3] experimented on the rubber seed oil and concluded that carbon deposits are more due to incomplete combustion. Deepak Agarwal et.al [4] investigated on Jatropha oil and blends. In preheated, the result shows that BSFC and EGT for neat Jatropha oil were found little higher than that of the diesel and preheated Jatropha oil. The thermal efficiency was lower for neat Jatropha oil compared to preheated Jatropha oil and diesel. $\mathrm{CO} 2, \mathrm{CO}, \mathrm{HC}$ and smoke opacity were higher for Jatropha oil than diesel.

Jagadale et.al [5] had studied on single cylinder diesel engine using blends of ester or chicken fat with diesel. The performance was nearer to that of diesel fuel and smoke emission as well. Alp Tekin ERGENC et.al [6] had used ester of soyabean blends. In that, the maximum torque generated by the B20, B50 blends was higher than that of diesel fuel. $\mathrm{CO} 2, \mathrm{CO}$ and $\mathrm{NOx}$ emissions are closer to diesel fuel. Anbumani et.al [7] have tested on blends of mustard and neem oil in diesel engine, 20\% ester of mustard oil-diesel performed like diesel and emission as like a neat diesel.

Sudhir Ghai et.al [8] had used Sunflower methyl ester in diesel. The performance was better than the diesel mode operation. The UBHC emissions were less; 
NOx emissions were higher than the diesel. Lakshmi narayana rao et al [10] tested the blends of Rice bran methyl ester and diesel in direct injection diesel engine. The combustion parameter increases the nature of emission parameters and reduces in soot formation.

Sankaranarayanan et.al [11] had experimented mahua oil enrichment with hydrogen in compression ignition engine and had found the improvement in combustion performance, reduction in smoke, increase in NOx emissions with addition of hydrogen.

Naga prasad et.al [14] had studied the reduction in engine Performance for the blend of castor and diesel. Ekrem Buyukkaya [24] had conducted tests on the diesel engine, the performance and the emissions were studied. Higher BSFC, lower smoke \& CO emission were recorded. Mohamed Y.E. Selim et.al [15] had tested Methyl Ester of Jojoba as a fuel in a variable compression research engine Ricardo E6 engine at $1200 \mathrm{rpm}$. The parameters such as the EGT, the ignition delay period, the maximum pressure rise rate, maximum pressure, and indicated mean effective pressure and maximum heat release rate were noted. The engine performance was represented and the effects of both approaches were examined. Deepanraj et al [23] observed the effects of methyl esters of rice bran oil blend in a diesel engine. The engine performance was slightly lower than diesel and the smoke emission is lower and the NOx level is a little higher than diesel. Misra et.al [16] had tested soap nut oil $(10 \%, 20 \%, 30 \%$ and $40 \%)$ with diesel. The blending results that, SNO 10 performs better in the aspect of BTE and BSEC. All blends results higher $\mathrm{HC}$ emissions when it exceeds $75 \%$ of its full load. Blends SNO 10 and SNO 20 have lower $\mathrm{CO}$ emissions at full load. NOx emissions are lower for all blends. SNO 40 blend have 35\% reduction in NOx emission. SNO 10\% performs better in respect of performance and emission characteristics.

Usta et.al [17] have studied methyl ester of tobacco seed oil at full and partial loads. The results show that the use of methyl ester of tobacco seed oil in the diesel engine $\mathrm{CO}$ and $\mathrm{SO} 2$ emissions have reduced and NOx emissions had increased. The power and the efficiency slightly increased.

Gogoi et.al [18] found that methyl ester of Koroch seed oil show the higher BSFC and lower BTE for the KSOME blends. The engine IP was good for the blends up to B30 and for B40 blend it was reduced than that of diesel. Wail M. Adaileh et.al [19] had experimented Waste Vegetable oil (Cooking oil) with diesel and found increase in BSFC, BTE and EGT and $\mathrm{CO} 2, \mathrm{CO}$ are decreased with an increase of engine speed. Kasiraman, et.al [20] had tested cashew nut shell oil with diesel as fuel with addition of camphor oil blending and resulted that the performance combustion characteristics were good and NOx was reduced.

Mani et.al [21] had tested the waste plastic oil with variable injection timings $\left(23^{\circ}, 20^{\circ}, 17^{\circ}\right.$ and $14^{\circ}$ bTDC) and compared with the standard injection timing of $23^{\circ}$ bTDC. The retarded injection timing of $14^{\circ}$ bTDC resulting decrease in NOx, $\mathrm{CO}$ and $\mathrm{UBHC}$ and increase in the BTE, CO2 and smoke under all the test conditions. Purushothamman et.al [13] had tested neat orange oil with diesel as a fuel and results were longer ignition delay, higher combustion duration, peak pressure, and BTE and heat release rate compared with diesel. But $\mathrm{NOx}$ and $\mathrm{CO}$ emissions are increased. $\mathrm{HC}$ emissions decreased than the diesel fuel. From the above, it is concluded that, most of the investigations are performed in various types of esters, prepared from different SVO and some investigations made on use of neat oils and its blend with diesel fuel and few methodologies adopted and tested in diesel engine.

In the present study, blends of diesel and Esters of Simarouba Glauca are chosen as a fuel for direct injection compression ignition engine. The various blending ratio of Esters of Simarouba Glauca with standard diesel fuel are prepared and the following investigations were carried out.

- The performance and emission characteristics of direct injection compression ignition engine were studied by using various blending ratio of SGE: Diesel B60, B70, B80, B90 and B100 at different loads like $0 \%, 25 \%, 50 \%, 75 \%$ \& $100 \%$ load of its Full load. The results were compared with that of the standard diesel fuel.

- The combustion parameters such as variation of cylinder pressure, heat release rate, peak pressure and ignition delay are discussed with respect to the crank angle. 


\section{TEST FUEL SIMAROUBA GLAUCA OIL}

Simarouba Glauca is an edible oil seed bearing ever green tree, which is well suited for warm, humid, and tropical regions. It is suited for temperature range's of $10 \mathrm{OC}$ to $40 \mathrm{oC}$. The tree is now found in different regions of India. It can be grown on waste tracts of marginal, fallow lands of South India. The tree is native to central and North America. It can grow at elevations from sea level to 1,000 meters. It grows 40 to 50 feet tall and has a span of 25 to 30 feet. It bears yellow flowers and oval elongated purple colored fleshy fruits. The Fruits are collected in the month of April / May. When they are ripe they are dried in the sun for about a week. Seeds contain $60-75 \%$ oil that can be extracted by conventional methods. Each well-grown tree yields 15 to $30 \mathrm{Kg}$ nutlets equivalent to $2.5-5 \mathrm{Kg}$ oil and about the same quantity of oilcake. The oilcake being rich in nitrogen $(8 \%)$, phosphorus $(1.1 \%)$, potash $(1.2 \%)$, is good organic manure. The shells can be used in the manufacture of particleboard, activated charcoal or as fuel. The fruit pulp which is rich in sugar (about 11\%) can be used in the preparation of beverages. The oil can be also used for industrial purposes in the manufacture of biofuels, soaps, detergents, lubricants, varnishes, cosmetics, pharmaceuticals etc.

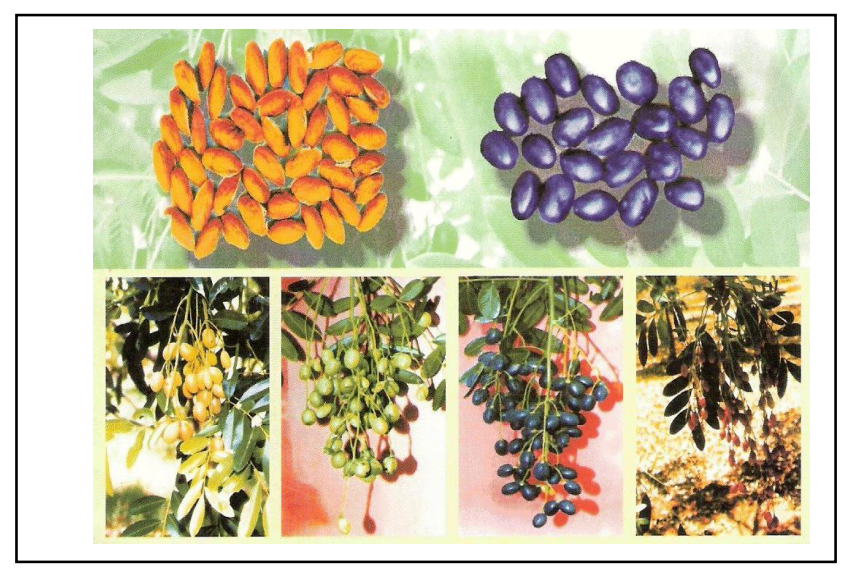

Fig. 1. Simarouba Glauca fruits and de-pulped seeds

\section{EXPERIMENTAL SETUP AND PROCEDURE FOR EXPERIMENTATION}

The engine used in this experiment was a single cylinder, 4-stroke DI diesel engine, the engine is coupled with an eddy current dynamometer through a load cell. The specifications of the engine and its instrumentation are shown in Table $1 \& 2$ respectively. All the experiments were conducted at standard temperature and pressure. The engine is integrated with a data acquisition system to store the in-cylinder pressure data for the off-line analysis. Cooling water is circulated separately to the dynamometer at the required flow rates. The essential provisions are made to regulate and measure the flow rates of air and fuel through electronic control unit. The engine is operated with diesel and dynamic fuel injection timing was set at $23^{\circ}$ BTDC and diesel as baseline mode at a constant speed of $1500 \mathrm{rpm}$ at no load to full load. While using blends the engine was started with diesel and switched over to blends and repeated in reverse before switching off the test rig. The engine was loaded with eddy current dynamometer and the loads were applied in steps of $0,25,50,75$ and 100 percent of full load. For each load, the engine performance parameters and engine emissions were recorded.

Fuel consumption was measured thrice by a burette attached to the engine. A stop watch was used to measure fuel consumption for every $10 \mathrm{cc}$ of fuel. Carbon monoxide, unburnt hydrocarbon and NOx emission were measured using Wahun Cubic Gas Analyzer. Smoke emissions were measured by means of Bosch smoke meter (GASBOARD-5020H). Chromyl-Alumel (k-type) thermocouple was used to measure the exhaust gas temperature.

Table 1. Engine specifications

\begin{tabular}{|l|l|l|}
\hline \multirow{2}{*}{$\begin{array}{c}\text { SI. } \\
\text { No. }\end{array}$} & \multicolumn{2}{|c|}{ Engine specifications } \\
\cline { 2 - 3 } 2 & Make and Model & \multicolumn{1}{|c|}{ Parameters } \\
\hline \multirow{2}{*}{2} & Keneral details & $\begin{array}{l}\text { Four stroke, compression } \\
\text { ignition, constant speed, } \\
\text { vertical, air-cooled, direct } \\
\text { injection }\end{array}$ \\
\hline 3 & $\begin{array}{l}\text { Number of } \\
\text { cylinders }\end{array}$ & One \\
\hline 4 & Bore & $87.5 \mathrm{~mm}$ \\
\hline 5 & Stroke & $110 \mathrm{~mm}$ \\
\hline 6 & Cubic capacity & $661 \mathrm{cc}$ \\
\hline 7 & Compression ratio & $17.5: 1$ \\
\hline 8 & Rated speed & $1500 \mathrm{rpm}$ \\
\hline 9 & Rated output & $4.4 \mathrm{~kW}$ \\
\hline 10 & $\begin{array}{l}\text { Fuel injection } \\
\text { timing }\end{array}$ & $23^{\circ} \mathrm{bTDC}$ \\
\hline 11 & $\begin{array}{l}\text { Diesel injector } \\
\text { opening pressure }\end{array}$ & $180 \mathrm{bar}$ \\
\hline 12 & $\begin{array}{l}\text { Nozzle hole } \\
\text { diameter }\end{array}$ & $0.23 \mathrm{~mm}$ \\
\hline 13 & Number of hole & 3 \\
\hline
\end{tabular}


Table 2. Engine's instrumentation specifications

\begin{tabular}{|l|l|l|}
\hline \multirow{2}{*}{ SI. } & \multicolumn{2}{|c|}{ ENGINE'S INSTRUMENTATION } \\
\cline { 2 - 3 } SoECIFICATIONS
\end{tabular}

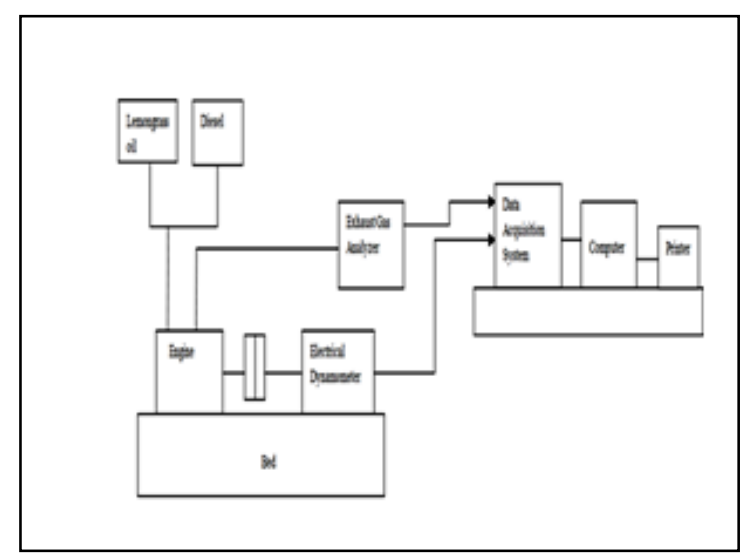

Fig. 2. Engine test setup

The engine was started by using standard diesel and the engine operating temperature was reached. The loads were applied. The test is conducted at the rated speed of $1500 \mathrm{rpm}$. In every test, the volumetric fuel consumption and exhaust gas emissions such as carbon monoxide (CO), hydrocarbon $(\mathrm{HC})$, nitrogen oxides (NOx), carbon dioxide (CO2) and oxygen (O2) are measured. From the initial measurement, brake thermal efficiency (BTE), specific fuel consumption (SFC), brake power (BP), indicated mean effective pressure (IMEP), mechanical efficiency and exhaust gas temperature for different blends were recorded. For every load condition the combustion characteristics and exhaust emission levels were also processed and stored in computer for future use. The same procedure were repeated for different blends of Ester of Simarouba Glauca oil. The properties of the diesel and Simarouba Glauca oil are summarized in Table 3. The actual density, viscosity, fire point, flash point and gross calorific value were measured in the laboratory.

Table 3. Properties of Simarouba Glauca oil

\begin{tabular}{|c|c|c|c|}
\hline \multirow[b]{2}{*}{$\begin{array}{l}\mathrm{SI} \\
\mathrm{N} \\
0\end{array}$} & \multicolumn{3}{|c|}{ Properties of Simarouba Glauca oil with Diesel } \\
\hline & Properties & $\begin{array}{c}\text { Methyl ester of } \\
\text { Simarouba } \\
\text { Glauca }\end{array}$ & Diesel \\
\hline 1 & Flash point & 141.2 & 74 \\
\hline 2 & $\begin{array}{l}\text { Kinematic Viscosity @ } \\
40 \mathrm{C} \text { in CST }\end{array}$ & 5.4 & $3-4$ \\
\hline 3 & $\begin{array}{l}\text { Lower heating value } \\
\mathrm{kJ} / \mathrm{kg}\end{array}$ & 38485 & 42700 \\
\hline 4 & $\begin{array}{l}\text { Density @ } 40^{\circ} \mathrm{C} \text { in } \\
\text { gm/cc }\end{array}$ & 0.84 & 0.8752 \\
\hline
\end{tabular}

\section{RESULTS AND DISCUSSION}

\section{A. Performance and combustion analysis}

\section{1) Brake thermal efficiency}

The figure 3 shows the variation of brake thermal efficiency for the blends of higher proportion SGE and diesel. The trend shows the similar pattern for all the blends operating from no load to full load. However all the blends are reported as lower performing compared to diesel fuel at all loads. From the graph the performance of the blends are seen in the descending order as follows, diesel, B60, B70, B80, B90 \& B100. At full load the BTE is $28.3 \%$, is $26.52 \%, 24.23 \%, 22.87 \%, 23.92 \%$ \& $22.69 \%$. From the combustion behavior, the blend B60 shows a closer performance with diesel better than B100 \& other blends. The decrease of BTE for B60 is $6.52 \%$ and for B100 is $20 \%$ than that of diesel. The reduction of fuel viscosity improves fuel spray, fuel atomisation and better air entrainment which aids the combustion. The ignition delay of the blends is more than diesel. 




Fig. 3. Brake thermal efficiency

\section{2) Combustion Chamber pressure}

The figure 4 shows the ( $p-\oplus$ pressure-crank angle diagram for all blends for $75 \%$ of full load. The pressure history gives a lot of details about the engine behavior for the tested fuel. From the data the ignition delay period can be determined. The ignition delay period is determined by the difference between angle at which the injection starts and the angle at which the combustion just starts.

The start of combustion is calculated from the change of the slope on the pressure crank angle diagram or from the heat release analysis or from the luminosity detection experimentally. Usually needle lift indicator indicates the start of injection but it is too difficult to precisely note the start of combustion. The ignition delay for the diesel is 19 ${ }^{\circ} \mathrm{CA}, \mathrm{B} 60$ blend is $20^{\circ} \mathrm{CA}, \mathrm{B} 70$ blend is $20^{\circ} \mathrm{CA}, \mathrm{B} 80$ blend is $19^{\circ} \mathrm{CA}, \mathrm{B} 90$ blend is $19^{\circ} \mathrm{CA}$ and $\mathrm{B} 100$ is $18^{\circ} \mathrm{CA}$ for 75 $\%$ of full load. Further the ignition delay for all the tested fuels at lower loads is higher and getting reduced as the loads is increased.

The peak pressures developed for diesel is 63.06 bar at $8^{\circ} \mathrm{ATDC}$, for $\mathrm{B} 60$ blend is 62.214 bar at $6^{\circ} \mathrm{ATDC}$, for $\mathrm{B} 70$ blend is 62.99 bar at $7^{\circ}$ ATDC, for B80 blend is 63.073 bar at $7^{\circ}$ ATDC, for $\mathrm{B} 90$ blend is 62.707 bar at $9^{\circ}$ ATDC and for B100 blend is 63.3 bar at $8^{\circ}$ ATDC observed at $75 \%$ of full load. The biodiesel blends possess viscosity which increases as the blend ratio increases. The increased viscosity of the blend reduced the atomisation quality of fuel. This would increase the droplet size of the injected fuel and increases the breakup time. This increases the physical delay and subsequently the chemical delay too except B100 which causes the accumulation of fuel and lead to increase peak pressure.

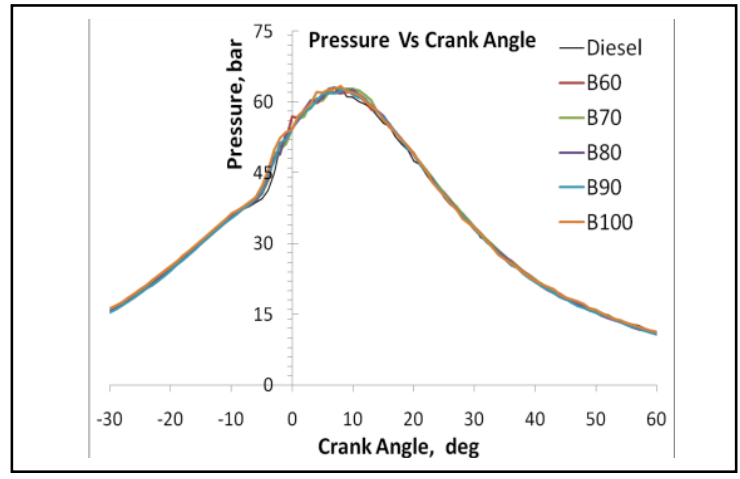

Fig. 4. Combustion chamber pressure

Table 4. Peak Pressure and Ignition Delay

\begin{tabular}{|l|l|l|c|}
\hline \multirow{2}{*}{$\begin{array}{c}\text { SI. } \\
\text { No. }\end{array}$} & \multicolumn{3}{|c|}{ Peak Pressure and Ignition Delay } \\
\cline { 2 - 4 } & Blends & $\begin{array}{l}\text { Peak } \\
\text { Pressur } \\
\text { e }\end{array}$ & $\begin{array}{l}\text { Ignition } \\
\text { delay }\end{array}$ \\
\hline 1 & DIESEL & 63.06 & 19 \\
\hline 2 & B60 & 62.21 & 20 \\
\hline 3 & B70 & 62.99 & 20 \\
\hline 4 & B80 & 63.07 & 19 \\
\hline 5 & B90 & 62.71 & 19 \\
\hline 6 & B100 & 63.30 & 18 \\
\hline
\end{tabular}

\section{3) Heat release rate}

The figure 5 shows the combustion and heat release patterns for all the tested fuels at $75 \%$ of full load. The difference in fuel properties of diesel and biodiesel blends affects the combustion and heat release characteristics. Biodiesel shows the early start of combustion, lower heat release trend and biodiesel has lower heating value causes, loss in output.

The figure shows, initially a negative trend which indicates the heat release used by the fuel to vaporise during physical delay period and then increases to maximum takes place after TDC for all fuels. The burning duration is elongated which is seen in the figure for blended fuels. This indicates the heat release at diffusion combustion in case of blended fuels. The start of combustion and heat release of biodiesel blends could be due to the effect of micro emulsion which may affect the combustion. 


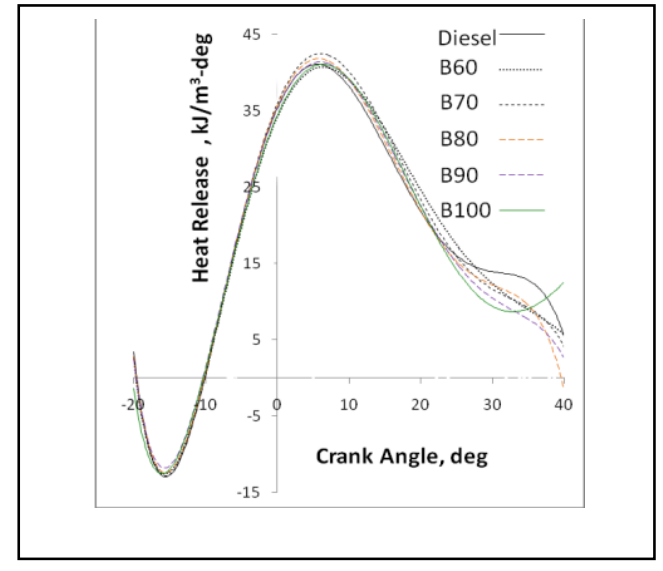

Fig. 5. Heat release rate

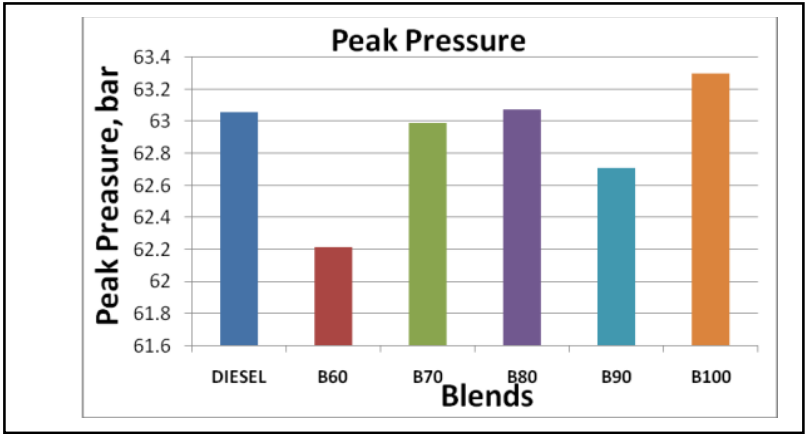

Fig. 6. Peak pressure

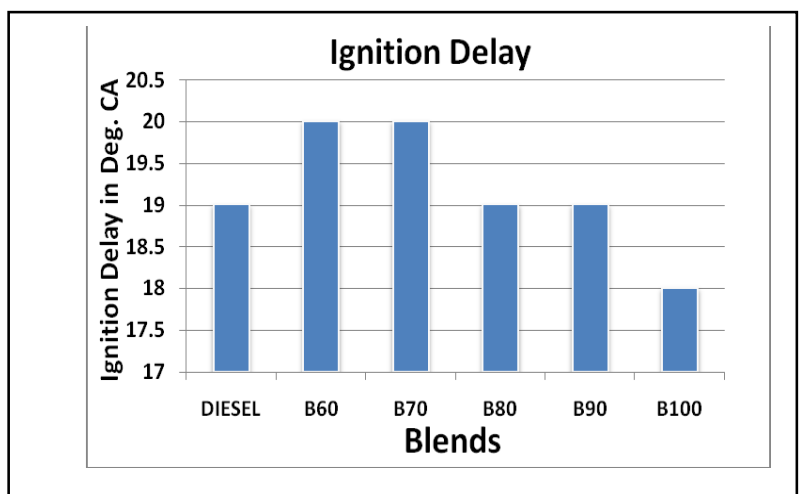

Fig. 7. Ignition delay

\section{4) Brake specific fuel consumption}

Fuel flow rate is measured during engine testing. The SFC is the fuel flow rate per unit of power. The SFC is a measure of an engine's fuel energy conversion efiiciency, which is more commonly termed as the thermal efficiency. The SFC and Engine thermal Efficiency are much related. The variation of BSFC for all blends of higher proportion SGE \& Diesel is shown in fig 8. The pattern of BSFC is very similar to that of a diesel. From the figure, at $75 \%$ of load the BSFC for Diesel, B60, B70, $\mathrm{B} 80, \mathrm{~B} 90$ \& $\mathrm{B} 100$ is shows as $0.3083,0.3269,0.3400$, $0.3429,0.3443 \& 0.3457$ respectively. The trend indicates the energy released by the blends is obvious. The lower blend of ester indicate the better performance and the influence of vegetable oil is only $60 \%$ by volume and only that effect the performance of blend in combustion \& energy release too.



Fig. 8. Brake specific fuel consumption

\section{5) Exhaust gas temperature}

The figure 9 shows the trend of exhaust gas temperature for various blends of higher proportion SGE and diesel for various loads. From the chart it is found that EGT is a linear function at lower loads. At part load condition the EGT for all blends are nearly closer to diesel. however as the load increases the EGT also increases. At full load for Diesel, B60, B70, B80, B90 \& B100 are observed as $338^{\circ} \mathrm{C}, 355^{\circ} \mathrm{C}, 355^{\circ} \mathrm{C}, 360^{\circ} \mathrm{C}$, $345^{\circ} \mathrm{C} \& 348^{\circ} \mathrm{C}$ respectively. This is due to lower cetane number, increased ignition delay \& more accumulation fuel in combustion chamber \& caused delayed rapid combustion, resulting marginal increase in temperature. The increment in EGT might be due to the presence of oxygen in SGE, which is an oxygenated fuel and hence enhances the combustion.

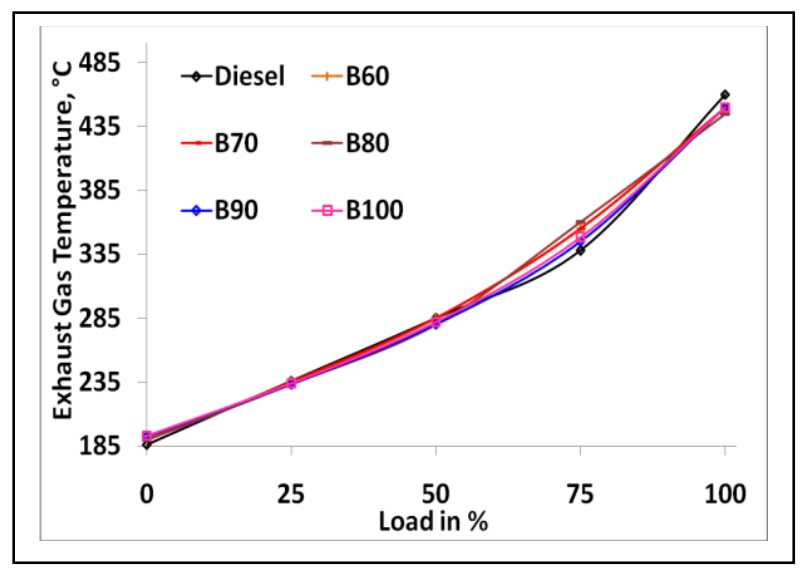

Fig. 9. Exhaust gas temperature 


\section{B. Emission Analysis}

\section{1) Hydro Carbon}

The characteristic of $\mathrm{HC}$ emission for various blends are shown in figure 10. For all blends of operation the trend is increasing as the load increases. Normally the diesel engines are emitting very low $\mathrm{HC}$ \& $\mathrm{CO}$ emissions due to its lean operation behavior than $\mathrm{SI}$ engines. At full load condition the diesel emits 30ppm, B60-16ppm, B7012ppm, B80-14 ppm, B90-12ppm \& B100-15ppm respectively. The reduction of $\mathrm{UBHC}$ is by $60 \%$ for $\mathrm{B} 90$ \& $50 \%$ for B100 than that of diesel.



Fig. 10. Hydro carbon

\section{2) Carbon Monoxide}

The Figure 11 shows CO Vs load for various blends of SGE for all loads. The curves show that the linear and similar value trend for part load operation however it increases at full load. At full load the diesel emits $0.63 \%$ and other blends as $0.2 \%, 0.13 \%, 0.17 \%, 0.16 \% \& 0.13 \%$ respectively.

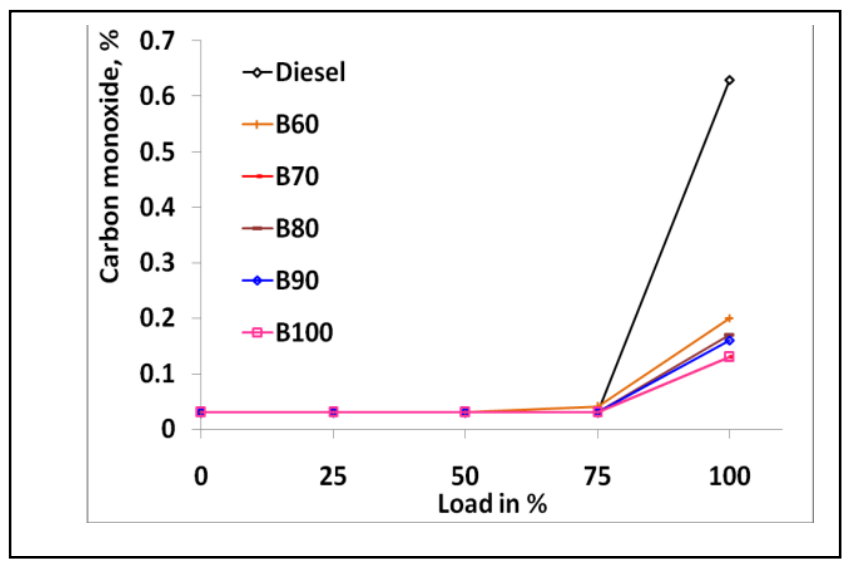

Fig. 11. Carbon monoxide

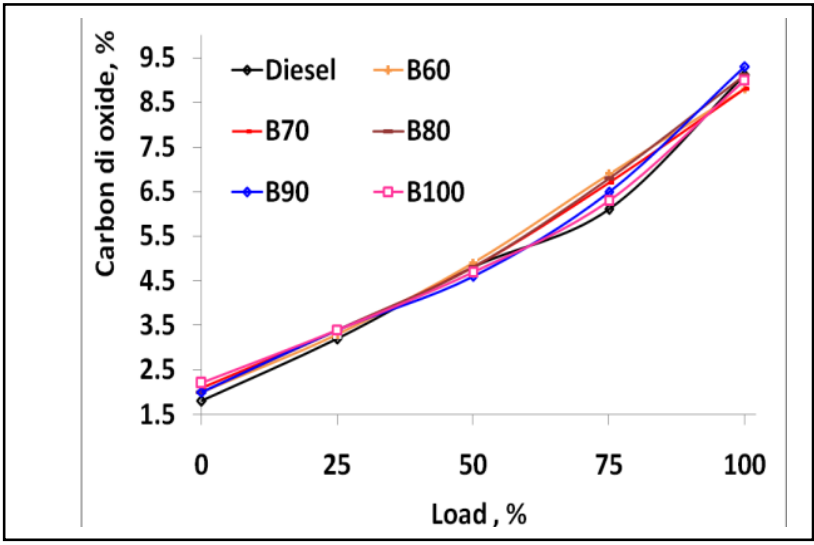

Fig. 12. Carbon-di-oxide

\section{3) Carbon-di-oxide}

The figure 12 shows the emission of $\mathrm{CO} 2$ for all blends of SGE. The trend is similar for all blends from no load to full load. The diesel shows $9.1 \%$ CO2 emission and the other blend $\mathrm{B} 60$ \& B70 emission were better than diesel (3.3\% lesser). B80 emission was equal to Diesel \& B90 increased by $2.15 \%$ and $\mathrm{B} 100$ is $0.01 \%$ higher emission than diesel.

\section{4) Oxides of nitrogen}

The figure 13 shows the trend of blends of higher proportion SGE and diesel from no load to full load. The chart characteristics is similar to all blends for all loads of operation. The NOx emission is due to fuel and combustion. If the peak flame temperature is high then the formation of NOx occurs. From the Figure, the diesel at full load is 870ppm, B60-1012ppm, B70-1147ppm, B80-1139ppm, B90-1190ppm and B100-913ppm. The reason for high NOx emission could be due to decrease in ignition delay for higher blends and the release of heat in the chamber resulting in high temperature and high NOx formation.

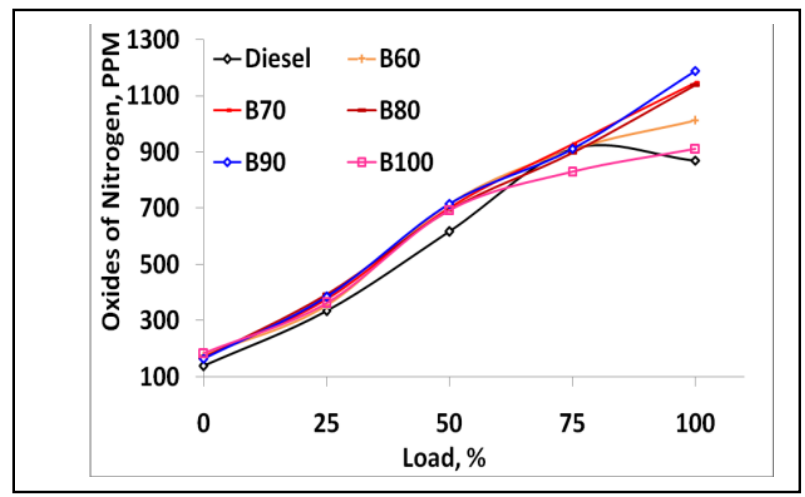

Fig. 13. Oxides of nitrogen

\section{5) Smoke}

The trend shows smoke emission of various blends and diesel from no load to full load. The significant smoke 
reduction is seen in figure 14 at full load for B100 are 42 $\%$, the diesel is $57.9 \%$ and the rest of the blends are falling in between. The smoke is mainly produced in the diffusive combustion phase. The oxygenated fuel blends lead to an improvement in diffusive combustion for blends. B80, B90 and B100 in particular have 46.7\%, $44.4 \% \& 42 \%$ respectively.

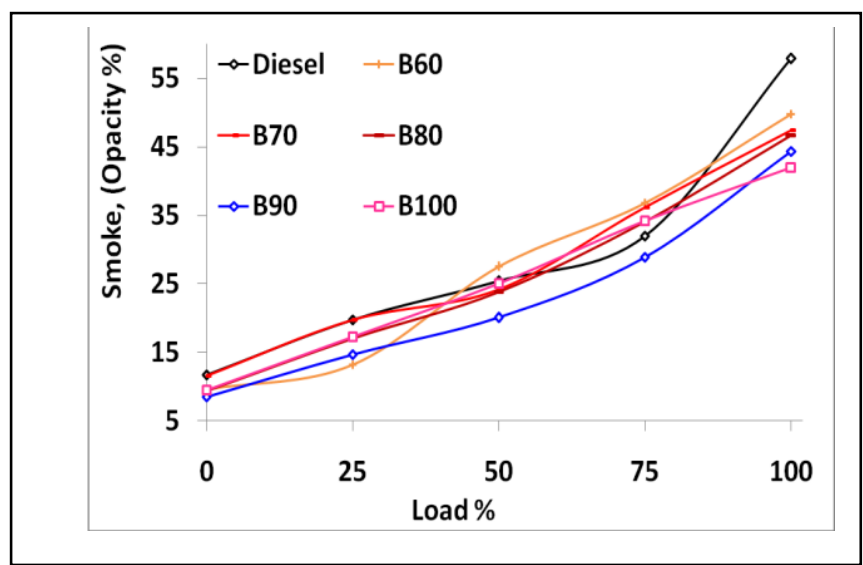

Fig. 14. Smoke

\section{CONCLUSION}

It is evident that the normally used blend is mostly B10 or B20 which are always indicating closer performance with diesel operation. This paper focused on the use of higher proportion of SGE diesel blends so that the use of diesel is brought to the minimum. The performance, emission and combustion characteristics of a direct injection diesel engine fuelled with Esters of Simarouba Glauca and diesel blends have been investigated and compared with the standard diesel fuel. The following conclusions are consolidated from the above investigation.

- The blend B60 shows a closer performance with diesel better than B100 \& other blends. The decrease of BTE for $\mathrm{B} 60$ is $6.52 \%$ and for $\mathrm{B} 100$ is $20 \%$.

- EGT for blends are marginally higher than diesel.

- At full load diesel emits 9.1\% CO2 and all other blends of SGE are closer to diesel.

- At full load the NOx emission for diesel is 870ppm, other blends are showing increase in trend and B90 emits highly 1190ppm.

- Smoke reduction in B100 is $42 \%$ than diesel of $57.9 \%$ at full load.
- The peak pressures are developed closer to diesel and showing marginal variations for all loads of operations.

- Biodiesel starts combustion early, releases lower heat.

\section{REFERENCES}

[1] Zafer Utlu, Mevlut Sureyya Kocak. The effect of biodiesel fuel obtained from waste frying oil on direct injection diesel engine performance and exhaust emissions. Renewable Energy 33(2008) 1936-1941.

[2] M.Pugazhvadivu, K. Jeyachandran. Investigations on the performance and exhaust emissions of a diesel engine using preheated waste frying oil as fuel.Renewable Energy 30(2005) 2189-2202

[3] A.S. Ramadhas, S. Jayaraj, C. Muraleedharan. Characterization: an effect of using rubber seed oil as fuel in the compression ignition engines. Renewable Energy 30(2005) 795-803

[4] Deepak Agarwal, Avinash Kumar Agarwal. Performance and emission characteristics of Jatropha oil (preheated and blends) in a direct injection compression ignition engine. Applied Thermal Engineering 27(2007) 2314-2323

[5] Jagadale S.S, Jugulkar.L.M. Performance characteristics of single cylinder diesel engine using blend of chicken fat based biodiesel. Int.J of Mechanical and Technology. Volume 3, Issue 2, Aug (2012), pp 754-768

[6] Alp Tekin ERGENC, Levent YUKSEK, Orkun OZENER. Perfomance, emission and heat release analyses of a direct diesel engine running on diesel and soybean ester blends. Turkish Journal of Engineering \& Environmental Sciences. (2013 37:23-32

[7] K. Anbumani and Ajit Pal Singh. Performance of Mustard and Neem oil blends with diesel fuel in $\mathrm{Cl}$ engine. ARPN Journal of Engineering and Applied Sciences. Vol.5, No.4, April 2010

[8] Sudhir Ghai, L.M. Das and M.K. Gajendra Babu. Emissions and Performance study with sunflower methyl ester as diesel engine fuel. ARPN Journal of Engineering and Applied Sciences. Vol.3, No5, Oct 2008.

[9] John B. Heywood-Internal Combustion Engine Fundamentals, McGraw Hill International Editions

[10] Lakshmi Narayana Rao GATTAMANENI, Saravanan SUBRAMANI, Sampath SANTHANAM, and Rajagopal KUDERU. Combustion and Emission characteristics of Diesel engine fuelled with Rice bran oil methyl ester and its diesel blends. Thermal Science: Vol.12 (2008), No.1,pp. $139-150$

[11] G. Sankaranarayanan, M. Pugazhvadivu. Effect of hydrogen enriched air on the performance and emissions of mahua oil fuelled diesel engine. Int.J.Renewable Energy Technology, Vol.3, No.1, 2012. 
[12] K.Muralidharan, D.Vasudevan. Performance, emission and combustion characteristics of variable compression ratio engine using methyl esters of waste cooking oil and diesel blends. Applied Energy 88(2011) 3959-3968

[13] K. Purushothaman, G.Nagarajan. Performance, emission and combustion characteristics of a compression ignition engine operating on neat orange oil. Renewable Energy 34 (2009) 242-245

[14] Ch.S.Naga prasad, K. Vijaya kumar reddy. Peformance and emission characteristics of a diesel engine with castor oil. Indian journal of science \& technology, Vol2, P 2531(Oct2009)

[15] M. Y. E. Selim, Mohsen S. Radwan and Soliman M.S. Elfeky, " Combustion of Jojoba Methyl Ester in an In-Direct Injection Diesel Engine, Renewable Energy Journal, Vol. 28, Issue 9, July, pp. 1401-1420, 2003.

[16] R.D. Misra, M.S. Murthy. Performance, emission and combustion evaluation of soapnut oil-diesel blends in a compression ignition engine.Fuel, Volume 90 , Issue 7, July 2011, Pages 2514-2518

[17] Usta.N, "An Experimental Study on Performance and Exhaust emissions of a diesel engine fuelled with tobacco seed oil methyl ester". Energy Conversion and Management 46(2005)2373-2386.

[18] T.K Gogoi, D.C. Baruah. The use of Koroch seed oil methyl ester blends as fuel in a diesel engine. Applied Energy (15 March 2011).
[19] Wail M. Adaileh, Khaled S. Alqdah. Performance of Diesel engine fuelled by a Biodiesel extracted from waste cooking oil. Energy Procedia, Volume 18, 2012, Pages 1317-1334

[20] G. Kasiraman, B. Nagalingam, M. Balakrishnan.Performance, emission and combustion improvements in a direct injection diesel engine using cashew nut shell oil as fuel with camphor oil blending. Energy, Volume 47, Issue 1, November 2012, Pages 116124

[21] M. Mani, G. Nagarajan. Influence of injection timing on performance, emission and combustion characteristics of a DI diesel engine running on waste plastic oil.Energy, Volume 34, Issue 10, October 2009, Pages 1617-162

[22] Balajee.D,Sankaranarayanan.G,Harish.P and Jeevarathinam.N, "Performance and Combustion Chracteristics of $\mathrm{Cl}$ Engine with Variable Compression Ratio Fuelled with Pongamia and Jatropha \& its Blends with Diesel", Published in International Journal of Mechanical Engineering and Robatics Research (IJMERR), ISSN 2278 Vol 2, No 3, July 2013.

[23] Deepanraj.B, Lawrence.P, Sankaranarayanan.G, "Performance and emission Characteristics of Diesel Engine Fuelled with Rice bran oil Methyl Ester Blends", Daffodil University Journal Science and Technology Vol 7, Issue 2, July2012

[24] Ekrem Buyukkaya. Effects of biodiesel on a DI diesel engine performance, emission and combustion characteristics. Fuel 89 (2010)3099-3105 